\title{
Banking and business of interest in Early times of India (Special reference with inscriptions \& dharmasastras)
}

\author{
Gundala Mannepalli* \\ Department of History, Acharya Nagarjuna University, Nagarjuna Nagar - 522 510, A.P., India.
}

\begin{abstract}
King's spies disguised as merchants may borrow from corporations bar gold and coined gold for various kinds of merchandise to be procured from abroad no hint is available from arthasastra that the guilds were functioning as banks for the public in general. Kautilya mentions some extra qualities which were necessary for a guild to function as bank. This shows that not all the guilds were capable to function as banks. The receiving guild was expected to relieve misery it also points to the fact that the guilds had to be necessarily wealthy in order to be in a position to render help by making advances on interest. It is also likely that some fee was charged from those who received instruction. The guild should enjoy the confidence of other guilds. This point is significant as financial matters could only be entrusted to reputed institutions. The receiving guild should also be adequately competent to undertake any artistic work expected from it. We have seen till now how deposits, pledges mortgages and endowments were made in various places by different persons from time to time. In all such transaction, interest always played a prominent if not the most important role. The levying and recovery of interest have been two of the most vital functions of banking in India from early ages. Interest ware one of the essential factors between debtors and creditors in their various transactions. The welfare of the Kingdom depends on the nature of such transactions they should always be scrutinized.
\end{abstract}

Key words: compound interest,periodical interest,corporal interest,pledges ,mortgages, foreign trade interest

\section{Introduction}

Being an economic institution and having great wealth at their disposal, the guilds also served as banks in Ancient India. Money saving as a measure of safety in times of stringency has always been prevalent. In the absence of institutions like bank, usually floors and walls of houses, river banks and forests were chosen as place for storing money. But there was always the fear of money being stolen or lost in one way' or the other (Jat. Vol.1, No.40, p.227).

But we do not find the guilds acting as banks in the pre-buddhist period, in the succeeding centuries the guilds definitely emerged as established banking institution. There are adequate evidences to prove that they received public property, paid regular interest on the same and lent money to needy person in a passage of the Arthasastra, Kautilya speaks of despite of guilds .The passage runs, "Those who can be expected to relieve misery, who can give instructions to artisans, who can be trusted with deposits, who can be relieved upon by guilds of artisans may receive the deposits of guilds. The guilds shall receive their deposits back in times of distress". (Arthasastra, IV, 1).

Elsewhere also he attests to their function of money- lending when he says, "King's spies disguised as merchants may borrow from corporations bar gold and coined gold for various kinds of merchandise to be procured from abroad "(Ibid, V,2) no hint is available from these passages that the guilds were functioning as banks for the public in general. Kautilya mentions some extra qualities which were necessary for a guild to function as bank. This shows that not all the guilds were capable to function as banks. The receiving guild was expected to relieve misery. It also points to the fact that the guilds had to be necessarily wealthy in order to be in a position to render help by making advances on interest. Secondly, it was expected to be proficient in the craft which is under taken. It should have an established reputation as a school for imparting instruction to new artisans. It is also likely that some fee was charged from those who received instruction. Thirdly, the guild should enjoy the confidence of other guilds. This point is significant as financial matters could only be entrusted to reputed institutions. People should not run the risk of their money being lost or embezzled. The receiving guild should also be adequately competent to under take any artistic work expected from it.

1) To identify the business of interest in dharmasastras

\section{Objectives}

2) To identify the business of interest in inscriptions

3) To identify the types of business of interest in early times

4) To identify the influence of business of interest on early socities 


\section{Evidences from inscriptions}

It should enjoy a good reputation in artistic field as well so that the other guilds also could have their requirements fulfilled. This hints at their extra-professional qualifications. Finally, the guild should carry the confidence of the depositors. Kautilya further observes that the depositor guild could receive its deposits back in time of distress. It seems that, in times of financial stringency, the depositor guild could draw its money back. (E.I.E.H, p. 664).

A Ksatrapa inscription of Usavadatta, the son-in-law of the Ksatrapa king Nahapana. (Nasik cave inscription) dated 119-24 AD records a permanent endowment of 3000 Karsapanas invested with two weaver's guilds at Govardhana. Out of this two thousand Karsapanas were deposited with a weavers' guild at a rate of $1 \%$ interest per month.

The remaining one thousand were deposited with another weavers guild at rate of $3 / 4 \%$ interest per month. Usavadatta invested this money for the community of monks hailing from the four points of horizon living in the cave for defraying their expenditure on clothes and on paying the cost of Kusana (Pocket money). These Karsapanas were not to be repaid by one who paid the interest. All this was proclaimed in the guild hall and was written on boards according to the custom. This inscription also tells us. The rate of interest was highBrahman had to pay $2 \%$, Kshatriya $3 \%$, Vaisya $4 \%$ and Sudra $5 \%$.

(A.S.W.I. Vol. IV, No.7, p. 102, D.C. Sircar, selected inscription, p. 157, Luder List No. 1133, E.I. Vol. VIII, No.12, p. 82)

In another Nasik cave inscription of Isvarasena, there is reference to a perpetual endowment being made by Vishnudatta to provide medicine for the sick among the community of Buddhist monks dwelling in the monastery on the Trirasmi Mountain. A thousand Karsapanas were deposited with the guild of Kalikaras (Potters), two thousand with the guild of manufacturers of hydraulic engineers (Odayantrikas), five hundred with another guild whose name is lost and some more with the guild of oil-millers (Tilapisoka). Details regarding the rate of interest have also been mutilated. The expression Sugatanagatasu is intended to commit the specialized guilds existing at the time and their successors to the payment of a perpetual interest. (ASWI, Vol. IV, No.12, p.103, No. 1137)

An inscription at Nagarjunakonda, dated $333 \mathrm{AD}$, refers to a permanent 'endowment' created by a person for the maintenance of the religious establishments made by him. The endowment consisted of a deposit of 70 Dinars in one guild and 10 each in three other guilds out of the interest of which specific acts had to be done. Only names of two guilds are legible, namely those of Panitha (Propably sellers or growers of betel leaves) and Pavaka (confectioners), (EP. Ind. XXXV, p.5).

Which seem to record similar investments with various guilds, but as their purport has not been made out with certainly, no reference is made to them. The three inscriptions, quoted above, are, however, calculated to throw a flood of light on the function and organization of the ancient guilds.

Thus three inscriptions conclusively prove that guilds in Ancient days received deposits of public money and paid regular interest on them. Roughly speaking, therefore, they must be said to have served the functions of modern banks.

According to Nasikcave inscription of Usavadatta. The interest on 2000 Karsapanas was $12 \%$ per annum. While the interest on 1000 Karsapanas was $9 \%$ per annum. The reason which caused this difference in the amounts deposited. Hence the first guild, which received the larger sum, agreed to pay more interest than the second which received the lesser amount. But this assumption is beset with difficulty. We know from a contemporary Nasik inscription that a deposit of 100 Karsapanas only also yielded an interest at the rate of $12 \%$ per annum (EI, Vol. VIII, p. 90, No.17)

Some times the interest comes down to $6 \%$ annually. The extent epigraphs of the Deccan, therefore, refer to three different rates of interest, viz., $12 \%, 9 \%$ and $6 \%$. The highest known rate, i.e., $12 \%$ however was lower than the rates prescribed in the Law books (AS, III.II) and this was because of the better security afforded to the depositors. "The low rate of the interest in fact is an index at once of the security and stability of the banks, their efficiently, permanence and prosperity which attracted to them even royal deposits and benefications" (RK. Mookerji, Local Govt. in Aciant India, Inc. p. 98, 1958 Delhi).

It has been suggested that some of the Western Indian Buddhist Monasteries, of which we come to throw from the inscription found at Nasik, Junnar, Karle and Nanaghat, had accumulated of wealth, received through generous gifts, and that they invested part of it in business.

Their mercantile function was to supply capital loans and provisions to the trade- caravans. The cave monasteries were located conveniently near the interconnecting trade-routes covering a wild port of Western India. Prof. Kosambi, who was propounded this theory, thinks that the mulasarvastivadin and mahasanghika schools of Buddhism, which dominated this part of the country changed the strict vinaya rules without deviating from the letter and made it possible for the monasteries to indulge in such apparently mundane pursuits. (JBB RAS, XXX 1956, p. 50F) (Kosambi-Dhenukuta). 
We know from the Nasik inscriptions that money was left by devotees with the local guilds so that interest on it would go to the Buddhist monasteries. Had the monasteries themselves been engaged in businessespecially when they required liquid money to supply loans as has been suggested-why was money invested in the guilds ? There is no Direct Evidence.

We have references to the gift of money and land to Brahman and various religious institutions from early times but we do not know whether there was anything like temple trade in Ancient India. (G.L. Adhya, 1966-Bombay).

\section{The Theories of Interest}

We have seen till now how deposits, pledges mortgages and endowments were made in various places by different persons from time to time. In all such transaction, interest always played a prominent if not the most important role. The levying and recovery of interest have been two of the most vital functions of banking in India from early ages. Interest ware one of the essential factors between debtors and creditors in their various transactions. Kautilya observed that, as the welfare of the Kingdom depends on the nature of such transactions they should always be scrutinized. (Kautilya arthasastra Book, III, Ch.IX, p. 197, Text p. 174).

This implied that public welfare depends largely on the dealings between debtors and creditors and in such dealing interest played a very vital part. Debts were not recovered if they were neglected for ten years and also from persons aged, diseased or involved in calamities while travelling abroad or had fled the country. But such non-recoveries had two exceptions. One was in the case of minors and the other, during disturbances in the Kingdom (Ibid.B.III, Ch.XI, p.174). These exceptions reveal Kautilya's considerations for minors and shrewdness in foreseeing eventualities of national commotions either within or without a kingdom (Ibid, p. 198, text p. 174).

He had made such exceptions in the cases also of diseased persons and minors in so far as the accumulation of debts was concerned.

\section{Definition of Interest}

What then was this interest and why was it levied? The answers to these questions can be found in a definition of Narada who observed that a contract of delivery and receipt could be made with a view to profit arising from a station (sthana), that it was called Kusida or lending money at interest and that money lenders made a living by it (Narada I (6), (98), p.65).

A security of this definition reveals that the profession of money-lending as a means of livelihood was recognized as legal. But how was it to be executed? Brhaspati recommended that a creditor was never to lend money, without first having secured a pledge of adequate value or a deposit or a trustworthy surety or a bond written by the debtor himself or attested by scribing witnesses. (Brhas. XI (1), pp. 319-20).

All these conditions indicate that the creditor had to secure himself by all these recognized means in order that the amount, which was about to be lent, might not be lost.

\section{Views of Panini}

Early concept of the ideas of interest may be seen in Panini, who refers to several types of it. His expression dasaikadasa, according to which a lender received back as a refund, by lending 10 (dasa) of 11 (ekadasa) amounting to $10 \%$ and this was censured by him as usurious. (Panini IV. 4.31, P.V. Kane, History of Dharma Sastras, 111 p. 418-33). He also mentions lesser or lower rates of interest, viz. $1 / 2$ a Karsapana per month calling it ardha and bhagika, amounting to $6 \%$ and such deals went by the names of ardhika and bhaisika (Ibid. V.1, 48-49, Panini). According to Kasika, this rate is to be understood as $1 \frac{1}{2} \%$ or $2 \frac{1}{2} \%$ monthly, making this rate vary between band 30\% per annum (Agarwala Indian as known to Panini (1.K.P), p. 275).

These types of interest have been interpreted variously. The dasaikadasa has been periodical, the Pancaka or Saptaka, yielding a profit of 5,7,100 or 1000 (Panini, V. 1.478) as stipulated, the parivriddhika, in which the capital, after a stipulated period, doubled itself, compound interest (Ibid, VI. 2.38) and lastly stated boddhah, viz., bound for a debt of one hundred. (Ibid II. 3.34) as Corporal interest (Agarwal, (I.K.P.) p. 278).

In referring to these rates, Panini states that they could be levied in their respective conditions. Specify by name the various types of interest in to Compound, Corporal, Stipulated, Daily and others, which became current later on.

\section{Types of Interest}

There were various types of interest, quite distinct in nomenclature, rate, nature and periods of payment. They went by the names of compound, periodical, stipulated, corporal and cumulative interest. There were also other kinds of interest like those on pledges and their enjoyment, commercial interest which may be sub divided in to general interest, interest on commodities and on agricultural produce. Then there was what may be religious interest based on caste, daily interest and interest on mortgages. 


\subsection{Compound Interest}

The interest called compound went by the name of cakra-vriddhih and it is mentioned by manu as one of the forms of interest. (Manu VIII (151), p. 280). It is not mentioned by Kautilya who refers to other types of interest but why it was it is difficult to understand. Brhaspati first defined it as interest on interest (Brhaspati XI (5), p. 321). Narada, following this definition notes that along with the types of periodical and stipulated, compound. interest as a "the general rule" was payable on loans. (Narada I, 6 (104-5), p.67). We have no information whether this type of interest was popular or in which region or among which class of people it was current. This category of interest, though certainly beneficial to the lender, must have proved naturally very harmful to the borrower and it is not therefore surprising that its levy was considered usurious. As we shall see, inspite of its currency, not only was it condemned by manu (Manu VIII (157) p. 282) but also by Brahspati. Referring to the use of pledge, after twice its value was realized, he plainly stated that the imposition of compound interest and the exaction of principal and interest were condemned as reprehensible usury. (Brhaspati XI (1-6), p. 319).

\subsection{Periodical Interest}

Another type of interest, levied periodically, signifying time of period. Brhaspati noted that it was calculated on a monthly basis, being payable every month. This definition was also followed by Narada as in the case of compound interest, who defined it stating that it ran by the month (Narada, 1(103), p. 321) thus far agreeing with Brhaspati (Brhas XI (b), p. 321) fully. This kind of interest must have been comparatively more favourable than either the compound or daily varieties, about which we shall discuss presently, as it was covered not on a daily basis or on the interest levied, but by the month. Kautilya, for instance, refers to the rate of ten percent per month as a type prevalent among the forest people. We shall deal with this class of interest when discussing the question of commercial interest but here it is cited only as an example of a case of interest levied monthly. For that matter, even according to Kautilya, a legitimate imposition of interest like the levy of ones Pana and a quarter percent was also charged monthly. (Kautilya, Artha BK III, Ch. XI. p.197, text p.175). In fact, other types of interest like communal interest and another kind prevalent among sea traders (Ibid, p. 197, text p. 174) of course at varying rates called marine interest; also seem to have been current at one time or other in India, atleast according to the legists.

\subsection{Stipulated Interest}

The stipulated type of interest implied that it was agreed to by the receiver on the basis of an agreement by the borrower. Brhaspati holds that this type interest, known to manu, was one actually assured by the borrower and in this connection the agreement of the lender is also implied, the ads that it had to be paid always, as stipulated by the debtor himself, over and above the ordinary rate of interest and which had been promised in times of distress. He further adds that, if the interest stipulated was to be paid for in any way other than the one agreed to; it was not to be paid. (Brhas XI (9), p. 321).

This definition this kind of interest comprised of two elements. First that it arose out of an agreement between borrower and the lender, on the basis of the formers is stipulation. Secondly, it was to be over and above the normal rate of interest agreed to in times of distress. In regard to the first element, Narada explains that interest, declared by the debtor himself, was known as the stipulated rate: (Narada, 1.6 (103), pp. 66-67).

This implies that the stipulated rate, though its agreement by the lender is to be taken for granted, appears to have rested more on the borrower than on the lender, as the rate is said to have been warranted by the borrower himself. But, in actual practice, such as agreement could only have been practicable, valid and possible on the mutual agreement between the borrower and the lender, as regards the rate period and nature of payment of the interest agreed to between both the parties concerned in Sucha pact.

The other element, namely, it's having been in excess over and above the normal rate and also to the one agreed to in time of distress. Indicate that it must have been a high rate and restored to only by those in extreme straits and had no other option excepting the money-lenders financial support. Manu notes how this kind of stipulated interest, being in excess of the normal role and also against the law, was not recoverable, that it was called a usurious method of lending and that its lender was in no case permitted to charge more than five in the hundred (manu VIII (157), p.282, text (152), p. 295). As this rate per month was over and above the normal rate levied, it must have proved indeed exorbitant and well deserved the condemnation at the hands of a law-giver no other than manu, the father of all legists. Twice this rate prevailed in the forest region and far times this rate was the commercial interest charged at ten and five panas per month respectively. (Kautilya Artha BK III, Ch.XI, p. 197, Text, p. 174).

Katyayana introduced some new elements in to this type of the interest. According to him if the debtor had contracted in this case, in addition to the rate allowed by the sastras and which was under taken in times of difficulty, to pay a certain rate, such a rate had always to be charged though it was of the variety. 
But the interest of the pattern, incurred in other circumstances, was never to be paid (Katya, (498), p. 214). The implications of these views would mean that the rate was one which may be primarily associated only with emergencies and exigencies, that it was a kind of interest paid in excess over and above the normally sanctioned and approved rate of the legists and that, inspite of these excesses, it was permissible and hence legal to pay such an agreed rate. But the statement that the rate was never to be paid in other circumstances can only is understood to mean that in normal circumstances it was hardly either imposed or paid. This was one of the rates of interest which like commercial and special rates, must have weighed heavily on the poor and especially the working classes, if they had the misfortune to resort to the merciless money-lender, whose hands were strengthened by the legists that sanctioned it.

\subsection{Corporal Interest}

Manu's specification of the corporal brand of interest has been interpreted to mean corporal, namely, bodily or pertaining to human labour. (Manu VIII (153), p. 290)

Gautama characterized this kind of interest as a special exaction without specifying any details. (Gautama, XII (34-35), p.239). But it is Brahspati who throws some light on this type by stating that it was connected with bodily labour (Brhas. XI (6), p. 321).

Its precise rate as explained by Narada was at the rate of one pana or one quarter of a pana paid regularly without diminishing the principal (Narada, 1 (104), p. 67). The commentator Asahaya (Katyana Bhatta) explained it thus. This rate of a pana and a quarter was considered just by Kautilya (Kautilya Artha. BK III, Ch. XI, p. 174).

The rate or this amount must have been valued in terms of bodily labour which, according to Yajnavalkya, an indigent member of an inferior caste, being resourceless to pay the interest due, was made to work for his creditor. (Yajna II (44), p. 70)

As its precise rate has not been specified, it was probably calculated in terms of daily wages depending on the nature of the interest from the debtor.

\subsection{Cumulative Interest}

Perhaps Kautilya is the first writer to clearly refer or rather to allude to the cumulative nature of interest. He does this in his statement that interest on debts from persons, who were engaged in sacrifices which took a long time or who were suffering from disease or who were detained in the houses of their teachers or who were minors or too poor (Kautilya Artha BK III, Ch. XI, p. 198, text p.174) was not to accumulate. This certainly implies that, in cases other than these, interest was evidently allowed or legally recognised to aggregate. The exceptions made were clearly of those who were helpless to bear the burden of cumulative interest. Narada alluded to this type of interest when he observed that, it though proved by a debtor, A creditor failed to give an acquaintance for an amount paid to him by the debtor, thereafter that sum would yield to that debtor just as it had done to the creditor previously. (Narada 1, 7 (115), p. 69 text).

\subsection{Interest on Pledges}

Interest was also payable on the security of a pledge as can be seen from most of our law-givers. Manu inform us that, if a beneficial pledge viz. one from which profit accured was given, a lender was not to receive any interest on the loan advanced by him nor could he, after keeping such a pledge for a very long time, either give or sell it. (Manu VIII (143), p. 278, text (143). The interest on a pledge depended on the nature of such guarantee. If a pledge was to be only kept and not to be used by force and of a creditor, inspite of this directive, choose to use it forcibly, he had to surrender the entire amount of interest due to him. This was a view of manu. (Ibid (144), p. 294).

Again the fool, who utilized a pledge without its owner's permission, had to remit half of his interest as a compensation for such unauthorized use (Ibid (150), p. 280, text p. 295). Gautama, as we saw, remarked that the interest on a pledge depend on its use. Visnu, repeating what manu had stated, noted that by the use of a pledge which was only to be kept the interest accruing thereon was to be fortified (Visnu VI (5), p. 42).

He also observed that a pledge had also to be restored to the debtor, when the interest had reached its maximum, namely, when it became equivalent to the principal and all of it had been paid (Ibid (7), p.43).

Another aspect of this question was the interest earned by enjoyment and it arose out of the use of a mortgaged house or the produce of a field (Brhas XI (7-8) p. 3121) in such kinds of interest by enjoyment, interest had to be paid as long as the capital was unpaid. But the use of a pledge, after twice the principal had been realized from it. Compound interest and the exaction of the principal and interest together as principal, were deemed to be usury and condemned (Brhas (2), p. 322).

Yet on more feature of the interest arising from the benefit of a pledge was noticed by Katyayana. He observed that, when the complete enjoyment of the article pledged or mortgaged was agreed to be the interest, that transaction of money-lending was called adhi-bhoga (Katya (501), p. 215, text p.63). 
By this transaction interest seems to have been covered up not by any payment of a specific amount by the advantage of the article pledged. He further explained a little his interpretation of the term profit of enjoyment for, according to him, it arose when the leader derived pleasure from a mortgaged house by residing in it or by utilizing the crops from a mortgaged field (Ibid (500), p. 215, text p. 60).

\subsection{Interest on Mortgages}

Sometimes the interest on mortgages was specified further by our legists when it precise rates were laid down. Yajnavalkya observed that, in a loan or mortgage, the interest every month was $1 / 80^{\text {th }}$ part of the capital while, in the cases of other loans, it was 234 and 5 percent depending on the order of castes taking such loans (Yajna II (38), p. 68).

This view was also endorsed by Narada, who authorized a money-lender to take, in addition to the principal the interest fixed by Vasistha, one-eightieth part of a hundred in every month (Narada 1(99), p. 66). Vasistha declared that the rate was five months for twenty Karsapanas monthly (Vasista II, (51), p. 16). Gautama held that rate to be legal (Gautama XII (29), pp. 238-39). While manu citing vasistha also recommended it (manu VIII (140) p. 278). As Jolly had pointed out. This rule fixed the rate of interest at $1 \frac{1 / 4}{4}$ percent by the month or 15 percent per annum (CF. Narada f.n.op.66). Yajnavalkya recommended more rules on a mortgaged article, which was not to be made known, being used or rendered useless by continued use (Yajna II (60), p.73).

He held that the acceptance of an article, mortgaged and even it kept with proper care, suffered depreciation and that, consequently if the value of an article did not cover the capital and interest, other articles apparently to include then had to be mortgaged or the capitalist paid a portion of his due (Ibid (61), p.74). If any article was mortgaged under an agreement, confiding in the character of the mortgaged, the capital had to be paid with interest. The mortgage had to pay double the amount, if any article was mortgaged under an agreement (Ibid (62), pp. 73-74).

If the debtor came with the capital and interest, the article mortgaged had to be released by the creditor or else his conduct, being considered equivalent to theft, he was finished like a thief. The value of such an article, prevailing at that time, had to be settled and it had to remain three in the possession of the creditor without any further accumulation of interest. In the absence of the debtor, the creditor could sell the article but only in the presence of a witness, when the amount of a loan was given without any mortgage and it doubled with the interest due, the property could be released, under two conditions - if a plot of land was mortgaged again in satisfaction of the loan and if double the amount due could be realized from the produce of such a field (Ibid (64-65) pp. 74-75).

\subsection{Interest on Agricultural Produce}

We have already seen how the interest on again varied between five times and one-third of the value of the quantity pledged. According to Kautilya that interest on grains was not to exceed, in season of good harvest, more than half when value in terms of money. Interest on stocks was one half of the profits and it had to be regularly paid as each year expired. If it was allowed to accumulate intentionally or, in the absence abroad of either the receiver or payer, the amount payable was to be equal to twice the share of its principal (Kautilya Artha BK II, 1 Ch XI, pp. 197-98, text p. 174).

Therefore, according to this Kautilyan percept, interest on grains depend on the produce of the season; in a good season, however, it was not to exceed $50 \%$ of its value in cash. On stocks again interest was not to exceed the same rate of their profits, payable regularly at the end of the year. If this was not done, in view of any intention or the absence of any exemptions, these limits were applicable to all, in the Dharma sastras various rates in regard to the levying of interest on agricultural produce have been stipulated and we may, after mentioning them in some detail, draw the relevant inferences there from.

Manu held that on grain, fruit, wool or hair and beasts of burden, the interest was to be five-fold of the principal. There were slight variations in the rates given by the later legists. Yajnavalkya considered that on liquid substances like clarified butter, oil etc. female animals like a cow, the interest was eight times, while on looms of cloth, grains and gold, the interest was four, three and two fold of the original amount (Yajna, II (40), p. 69).

Brhaspati's rates were as follows: on gold other precious metals. It was double, on cloths, base metals like tin and lead, treble, on grain, four times, on edible plants, fruits, beasts of burden and wool, five times, on seeds and sugarcane, six times, on salt oil, spirituous liquor, sugar and honey, eight times, on women and cattle, it was the offspring. But on grass, wood, bricks, thread, substances from which threads may be extracted leaves, bones, leather, weapons, flowers and fruits, nothing was to be taken as interest (Brhas XI (13-16), p. 322) with Narada, on gold, grain and clothes, the rate increase to twice, thrice and four times the original amount, while on liquids, it was octuple (Narada 1, 6(107) p. 67). 
According to Katyayana, on jewels, pearls, gold, silver, fruits, silken cloth, woolens, the rate was double, on all oils and ghee, it was eight, fold and on all metals other than gold and silver, it was the maximum, eight-fold. (Katya (510-12), p. 217, text p.64).

\subsection{Daily Interest}

Yet another type of interest found in the Dharma Sastras was the Sikha-vriddhi which appears to have accrued daily and grew day by day. The fact that it is referred to by Gautama $\left(5^{\text {th }}\right.$ Century BC, Gautama XII (35) p. 239). Indicates that it must have been known and probably was also current in his day Gautama's comparison of it with the human hoir indicates that it must have increased slowly, steadily and relentlessly. This comparison was literally carried to its logical conclusion by Brhaspati in explaining if further. He stated that this kind of interest was received daily, growing like the hair and ceased only on the loss of the head, namely, the repayment of the principal. (Brhas xi (7-8), p. 321). At this rate it must have been a risky and dangerous usage but it is strength that it was not condemned as usurious by have givers like manu. This system was apparently rather faxing because according to this practice the interest had to be paid until the capital was repaid. This has been confirmed by Katyayana who, without making any contribution to the concept of this type of interest, observed that in this case the Debtor had to pay interest to the very end until the entire capital was repaid and he had to pay everyday (4990 p. 215, text p.62) If this kind of interest was to be paid daily and the amount borrowed was small, the inconvenience could not have been considerable but if it was large, the hardship must have been appreciable.

\subsection{Commercial Interest}

Another type of interest was the commercial, which may be sub-divided into two varieties- overseas and foreign trade and trade in general.

\subsection{Marine and Foreign Trade Interest}

In regard to over-seas and Foreign trade, Manu observed that whatever rate men, who were expert in sea-voyages and able to calculate the profit according to the place and time and the objects carried may fix, it had legal force and such interest was called marine (Manu VIII (157) p. 282 text p. 296) From this it would appear that the fixation of such a type of interest was left to the discretion of commercial experts who, from their experience of marine commerce, were expected to be in a position to fix it with regard to the location, period and the commodities carried during the voyage. This reflects the shrewdness and foresight of the law- giver manu in making such a recommendation.

Kautilya tells us that twenty panas per month percent was the rate that prevailed among sea-traders .From Yagna Valkya we learn that persons going to sea had to pay $20 \%$ as Interest. In view of the risk involved this rate was double that which traders had to pay when traveling through a forest, namely $10 \%$ (Kautilya Artha BK III, Ch. XI, p.1987, Text p.174) This would go to show roughly, that it must have been adjudged comparatively safer to go through "a dreary forest" infested with dangerous wild beasts and bandits equally harmful, than to brave the seas, reckoned to be twice as risky as a desolate Jungle. Even in the case of this type of interest, Yagna valkya observed that all castes had to pay interest in accordance with the ratios of their respective castes. It was to be in the scale of two, three, four and five percent in the case of Brahmanas, Kshatriyas, Vaisyas and sudras (Manu VIII (140-43) p.278.

That Brahmanas had to pay $22 \%$ of the marine Interest, Kshatriyas, $23 \%$, Vaisyas, $24 \%$ and Sudras $25 \%$ respectively. Such progressive rates must have been surely very detrimental to all classes and especially the sudras.

Kautilya had prescribed that any one levying a rate about $20 \%$ was to be punished with the first amercement, viz., a fine ranging from 48 to 96 panas (Kautilya Artha BK II Ch. XVII, p.217, text p. 12). Even hearers of such transactions had each to pay half of these seems as fines. (Ibid, BK III Ch. XI, p. 17, text, p.175). It can be understood how persons, who transgressed the rules of levying $20 \%$ of marine, interest, had to pay a penalty of the fine prescribed, but it is strange that even eaves- droppers of such deals were punished with half of the fine. The intension was no doubt to prevent even a verbal discussion of such an object and it could only have been enforced with the tremendous net-work of the espionage system envisaged by Kautilya. If cannot be otherwise considering feasible in a normal state, even granting the existence of a secret service or special police establishments.

\subsection{General Trade Interest}

In respect of all other transactions separate rates were charged. The commentator's medhatiti and others, in commenting on Manu's directive in respect of interest leviable in transactions pertaining to overseas and foreign trade (Manu VIII (157) p.282). Observed that such injunctions included all journey by land and all voyages. (Ibid. FN 57, p.282). 
Kautilya has pointed out that the leying of five panas per month percent was called commercial interest (Vyavahariki), namely $5 \%$. As in the case of the marine marine interest, any person who charged in excess of that rate was punished with the First Amercement, viz., 48 to 96panas and even those who heard about it had to pay a quarter of those lines (Kautilya Artha BK. III ch.XI. P. 197, text p.174).

Gautama in the $5^{\text {th }}$ century BC referred to a type of Interest which may well be christened commercial in connection with general transactions. According to him the Interest on products of animals, on wool, produce of a field and beasts of burden was not to exceed five-fold of the value of the objects lent.

Gautama, XII (36) p. 249. In this case also interest appears to have depended on the risk of the undertaking. Kautilya had noted that ten percent monthly prevailed in the forest regions (Kautilya Artha BK III Ch. XI, p.197 text. P.174).

Regarding that also, any excess charge was punishable with the first amercement and hearers of it too with half of that penalty. This rate evidently continued to the days of Yagna Valkya who noted how persons passing through lonely forest for carrying on trade had to pay (10\% as interest (Yagna II (38) p.68) as pointed out already this was probably not entirely because of the risk of going through such dense wildernesses alone but on account of the rate of $10 \%$ prevalent among the foresters.

\section{Conclusion}

From all these diverse details we may draw some conclusions. On commodities like fruit, wool and hair, evidently for blankets etc. The maximum laid down was five-fold. On liquid substances like clarified butter, oil, spirituous liquor, sugar and honey, the rate was eight-fold on cloth it was freble or quadruple. On grain, while manu held that it was five-fold of the value of the original quantity, with Yajnavalkya and Narada, it became $1 / 3^{\text {rd }}$, on seeds and sugar-cane it could raise up to six times its original value. On pearls and metals like superior gold and silver, it could be double while on baser metals, like tin lead and such ores it was treble. On live-stock like women and cattle, the interest was only on their offspring, which had evidently to be kept with the lender in the interest of security. The rate of interest thus, in all these cases, could vary from eight times the original value of the commodity in question to double that amount or the principal. But it must be noted that this rate was neither stable nor uniform in the cases of clothes, grain, fruits and woolens. It is strange that, in the category of live-stock, human beings, namely, women were also pledged and their offspring recovered as interest. It was to say the least an extremely monstrous practice and must have caused in expressible hardship to mothers and children, it was another aspect of slavery from the economic angle and only reveals the survival of a system betraying the great poverty which must have inspired its existence.

\section{References}

[1]. FACUS BOLL, V. (Ed). (1877-97), 6. vols. London, Jat Vol. 1 No. 40, p.227, Jatakas, Eng. Trans by Various Scholar under the editorship E.W. Cowell, 1895-1913. Cambridge

[2]. SHAMASASTRI, R. (Ed.) (1924) Arthasastra Eng. Trans R. Shamasastri,. Bombay, 1960.R.P. Kangle (ed) London, 1963.

[3]. SALETOER, R.N. (1964) Early Indian Economic History, - Popular Prakashan - Bombay, p.664

[4]. Archaeological Survey of Western India Vol. IV No. 7, p. 102

[5]. SIRCAR, D.C. south Indian inscriptions157 Luders List No. 1133 selected Inscriptions.

[6]. Epigraphia Indica Vol. VIII, No. 12, p.82,

[7]. Archaeological Survey of Western India Vol. IV, No.12, p. 103, Lud List No. 1137.

[8]. Epigraphia indicaXXXV. P. 5

[9]. Epigraphiaindica. Vol. VIII p. 90 No. 17.

[10]. MOOKERJI, R.K. (1958), Local Governaments in Ancient India Delhi. p. 98

[11]. Journal of Bombay Royal Asiatic Society XXX (1956). p. 50

[12]. ADHYA, G.L. (1966) Early Indian Economics, Asia Pub House Bombay p. 97.

[13]. SRINIVASACHARY, L. (1907) (Text edit)Bau Dhayayana- Dharma Sutra.. Trans in the S.B.E. series no XXII by George, Buhler Oxford 1889.

[14]. RANGA SWAMI AIYANGAR, A.V. (1941). (Edit) Brhaspati - Smriti .also text edited by mamatha nath Datt, Calcutta 1908. Trnas by Juliour Jolly S.B.E. XXIII Oxford 1889.

[15]. APTE, H.N. (1910) (Edited) Gautama-Dharma Sutra- with the Commentary of Haradatta, Trans by G. Buhler SBE.II.

[16]. SAMASASTRI,R.(1919) Kautilya : Arthasastra, text edited with the commentary of Dhattaswami by T. Ganapati Sastry mysore, 1924, also by K.P. Jayaswal, J. BORS, 1925, by R. Samasatry, Mysore 1919, Trans by Mysore, Trnas by R. Samasastri, $5^{\text {th }}$ Ed. 1956.

[17]. JOLLY,J.(1968)(edited) London Manu: Dharma Sastra, , , , manu samhita with the commentary of Kullaka Bhatta, Calcutta 1930, 2 Vols Trans by G. Buhler SBE Oxford 1886 also Text edited by J.R. Gitarpure, Bombay 1920.

[18]. JULIUS,(1885) Calcutta,( text exited).Narada: Smriti trans by J. Jolly (Sacred Book of East) XXXIII London 1876 also Naradiya Manu Samhita edited by Sambasiva Sastry, Trivandrum 1924.

[19]. DATTA, M.N. (1908) (edited) Calcutta Vasistha: Dharma Sastras trans. by G. Buhler S.B.E. Series XIV.

[20]. GOSWAMI SAMODAR (1929) (edited). Banaras Vatsayayana: Kamasutra edited with, the comentaries of Jayamangala and Yasodhara Satry. Trans by K.R. Iyengar Lahore 1921.

[21]. DATTA, M.N. (1909) (edited) Calcutta Vishnu: Dharma Sastra Trans by J.Jolly SBE II Oxford - Trans (OS) IV-VII.

[22]. HARINARAYAN APTE, (1903-04). Poona Yagna Valkya: Smriti with the commentary of Apararka by Aparaditya 2 Vols. Edited by A.S.S. No: 46

[23]. KASINADH PANDURANG PANDIT, (1909), (text edited) Bombay, Panini: Astadhyayi - Sutrapatha Trans by Srisa Chandra Vasi, Banaras 1897. 
[24]. AGARWALA, R.C.Format Texation as depicted in the Kharosthri Documents XXIV, PP. 340-353.

[25]. AGARWALA, V.S., (1953), India as known to Panini, The Vayu Parana - A study Varanasi, 1963.

[26]. DARIAN, S.G. (1988.) Anceint India and Ancient China, New Delhi,

[27]. RAY, H.P. (1986), Monastery and Guild: Commerce under the Satavahanas, New Delhi:.

[28]. SHARMA, R.S. (1987) Urban Decay in India, New Delhi,

[29]. SHARMA, R.K. (1988), Encyclopedia of Art, Archaeology and Literature in Central India, Aryan Books Delhi: 